\title{
Nā Inoa Hōkū: Hawaiian and Polynesian star names
}

\author{
Clive Ruggles ${ }^{1}$, Rubellite Kawena Johnson ${ }^{2}$ and John Kaipo \\ Mahelona $^{3}$ \\ ${ }^{1}$ School of Archaeology and Ancient History \\ University of Leicester, Leicester LE1 7RH, United Kingdom \\ email: rug@le.ac.uk \\ ${ }^{2}$ Center for Hawaiian Studies, University of Hawai`i at Manoa, Honolulu, Hawai`i, U.S.A. \\ ${ }^{3}$ Academia Language School, Honolulu, Hawai'i, U.S.A.
}

\begin{abstract}
In this paper we report on a 15-year project to construct a comprehensive catalogue of Hawaiian starnames documented in historical sources, published during the IAU General Assembly. Hawaiian star knowledge represents incomparable intangible heritage relating to Polynesian navigation in the Pacific. It both informs and motivates living cultural traditions aiming to reconstruct and build upon such knowledge.
\end{abstract}

Keywords. Astronomical heritage, Intangible heritage, navigation, cultural astronomy

\section{Introduction}

An extensively revised edition of $N \bar{a}$ Inoa $H \bar{o} k \bar{u}$, a catalogue of Hawaiian and Polynesian star names published by two of the authors 40 years ago (Johnson \& Mahelona 1975), has been published during this IAU General Assembly (Johnson, Mahelona \& Ruggles 2015). The first edition of $N \bar{a}$ Inoa Hok $\bar{u}$ contained many first-hand translations of primary sources researched in archives during the 1950 s to $1970 \mathrm{~s}$. Since that time, a number of new primary sources have been identified (e.g. Chun 2004), and these and other primary sources have been translated or re-translated as part of the project.

One of the major original goals was "To document what remains of a once flourishing mastery of celestial navigation by accumulating the star lore which has managed to survive centuries of meager regard". During the last four decades the reality of Polynesian and Micronesian navigation skills has become widely acknowledged, supported by a wealth of ethnohistorical, archaeological, and linguistic evidence (e.g. Kirch 2000; 2012; Kirch \& Green 2001).

It is no longer doubted that the sky occupied a prominent place in the rich cultural and historical legacy of the Hawaiian people - at many levels, and in many different ways. The new project, which has taken 15 years to complete, aims to provide a resource that will help to do justice to this undeniable fact.

\section{Issues and complexities}

While a number of Hawaiian star names are well known, a major challenge is to separate reliable first-hand information, mostly in Hawaiian-language archival sources dating back to the mid-19th century, from later commentaries and interpretations, many of which have introduced assumptions and errors that have become embedded in the literature. 
Some new star names have also been introduced recently, in the traditional style, as part of the living tradition of Hawaiian and Polynesian voyaging.

The sources, often fragmentary, reveal much more than just the use of star observations for navigation and wayfinding, hugely important as this was. There was no single tradition but a complex and dynamic body of astronomical knowledge. Particular star names are not always consistently applied to the same stars. Accounts of physical characteristics such as the dates and times of appearance and disappearance of particular stars do not necessarily make sense in a Western, objective sense: they may, for example, represent times when the asterisms in question became important for divinatory purposes. In short, there is no simple 1-to-1 correspondence between Hawaiian and Western star names.

Added to this, there is much confusion in the historical accounts and dictionaries owing to transcription and printing errors, ethnographer errors, and the fact that early Hawaiian texts lack diacritical markings that would have helped to clarify the intended meaning. Some translators added unsourced information of their own, and many Western "identifications" of indigenous star names have entered the literature in this way.

Such challenges make it all the more important to construct a resource that is as reliable as possible for future scholars, not only within Hawaiian cultural studies but also for comparative analyses with star names in other parts of Polynesia, which have the potential to shed important new light on beliefs and practices brought to the Hawaiian Islands by the earliest Polynesian settlers. The new edition of $N \bar{a}$ Inoa Hōk $\bar{u}$ aims to do this.

\section{Wider significance}

The star knowledge and navigation skills of Hawaiians and other Polynesians represent incomparable intangible heritage. The Polynesian Voyaging Society (www.hokulea.com), who are responsible for the many successful voyages of the sailing canoe Hok $\bar{u} l e^{6} a$, has done immense service in helping to reconstruct and revive these traditional concepts and practices. Our project aims to complement this by clarifying what is evident from ethnohistory. The historical and living traditions cannot be separated from each other. Knowledge and awareness of past traditions helps to generate respect for, and hence to protect and preserve, the living tradition. Looking backward provides a solid basis for looking forward, while looking forward gives the point to looking backward. As it is said

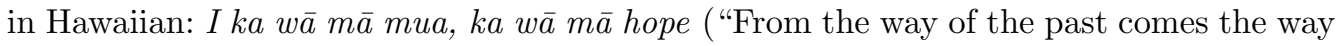
forward").

\section{References}

Chun, M. N. 2004, The History of Kanalu: Mo'okū'auhau 'Elua, by Benjamin K. Nāmakaokeahi (Honolulu: First People's Productions)

Kirch, P. V. 2000, On the Road of the Winds: an Archaeological History of the Pacific Islands before European Contact (Berkeley: University of California Press)

Kirch, P. V. 2012, A Shark Going Inland is my Chief: the Island Civilization of Ancient Hawai ${ }^{\prime} i$ (Berkeley: University of California Press)

Kirch, P. V. \& Green R. C. 2001, Hawaiki, Ancestral Polynesia: an Essay in Historical Anthropology (Cambridge: Cambridge University Press)

Johnson, R. K. \& Mahelona, J. K. 1975, Nā Inoa Hōkū: a Catalogue of Hawaiian and Pacific Star Names (Honolulu: Topgallant Books)

Johnson, R. K., Mahelona, J. K., \& Ruggles, C. L. N. 2015, Nā Inoa Hōkū: Hawaiian and Pacific Star Names (revised edition) (Bognor Regis: Ocarina Books) 